Agricultural Journal 14 (4): 70-74, 2019

ISSN: $1816-9155$

(C) Medwell Journals, 2019

\title{
Technical Efficiency of Maize Farmers in Oyo State, Nigeria
}

\author{
Idowu James Fasakin and Busayo Bidemi Akinbode \\ Department of Agricultural Economics, University of Ibadan, Ibadan, Nigeria
}

\begin{abstract}
There has been decrease in productivity of maize in recent time due to factors such as obsolete farm management practices, inadequate resource use fragile ecosystem, land tenure among others. Thus, this study examined technical efficiency among maize farmers in Oyo state, Nigeria. Primary data was collected through a multistage sampling procedure with stochastic frontier analysis as an analytical technique. Findings shows that there are more male $70.56 \%$, majority are married (76.49\%), $78.88 \%$ have either of primary, secondary and tertiary institutions with $34.4 \%$ of the farmers have access to credit. The mean farming experience is 7.11 years with $83.89 \%$ of the farmers having experience of ( $0-10$ years), mean income of the farmers is N51512.22 and average farm size 19.12 heatares.
\end{abstract}

Key words: Maize production, productivity, stochastic frontiers, Oyo state, Nigeria

\section{INTRODUCTION}

Globally, maize (Zea mays) is cultivated in about 160 countries on almost 150 million ha and contributes $36 \%$ (782 MT) in the global grain production (Rana et al., 2018). It is ranked third after wheat and rice in terms of world importance and known as the world's highest supplier of calorie (19.5\%) which is higher than the calorie supplied by rice (16.5\%) and wheat $(15.0 \%)$ (World Atlas, 2017). In sub-Saharan Africa, maize is the most important cereal crop which is grown by an estimated $50 \%$ of the total population in Africa. It is the main cereal crops of West Africa and the most important cereal food crops in Nigeria. An average of about 4.7 million tons of maize were produced between the year 1990 and 2015 in Nigeria with an output of 9,180, 270 metric tons in 2013 rated as the second grown food crop in the country after cassava which produced $52,403,455$ metric tons (FAO, 2013a, b). The cultivation covers about $561,397,290$ ha which is approximately $61 \%$ of total cultivable land in Nigeria and about $98 \%$ these maize farmers practice rain fed farming (FAO, 2017a, b). Also, Nigeria's Gross Domestic Product (GDP) grew by $1.95 \%$ (year-on-year) in real terms in the first quarter of 2018. This shows a stronger growth when compared with the first quarter of 2017 which recorded a growth of $-0.91 \%$ indicating an increase of $2.87 \%$ point.

The economic importance of maize cut across different spheres of human life, it also serves as food for human consumption such as pap, popcorn, thick porridge and boiled grains are notable food consumed by majority of Nigerians, chiefly in the Southern Nigeria (Olaniyan, 2015 and Oyewo, 2011). Industrially, maize constitutes the major ingredient of animal feed for poultry, brewery for beer and malt drinks, ethanol for bio-fuel, starch and syrup for medical uses (Monsanto, 2014), the starch can be used as converter dextrin, syrup and sugar; oil obtained from it is used to make soup or refine for cooking and salad dressing. Also, it is a source of employment for millions of Nigerians from the farmers that cultivate maize to all the value chain actors that are engage in its production to difference end use. In term of production, the accelerated growth started in the mid-1980s, when hybrids were introduced, e.g., open-pollinated varieties of extra-early-early-intermediate-and late-maturity with resistance to the parasitic weed Striga hermonthica and stem borers, exceeding the 5 million ha mark in the mid-1990's, following the introduction of early varieties. There was retardation in declining production of during the late 2000s, mainly due to drought and erratic rainfall but picked up thereafter. Currently it occupies the largest area of cultivated land in the country.

In recent times, there has been decrease in the productivity leading to fluctuation in maize production. The production was at 10.4 million tons in 2017 which is unable to meet the increasing population of the country (World Atlass, 2017a, b). Some factors contributing to the low productivity includes farm management practices, resource use, population pressure, fragile ecosystem, poverty, land tenure, inadequate knowledge on appropriate technologies, technical know-how, inadequate incentives, farmer's perceptions and attitudes which are inherently unpredictable among others (Ayinde et al., 2015). These factors influence and have effect on the production output and management practices as a whole, thereby leading to low productivity of maize in the country. Despite the large cultivation of maize in the country and its importance in the nutrition of people, it is not always available at a required quantity in Oyo state. This may not be unconnected to the fact that many farmers depend mainly on traditional method of farming

Corresponding Author: Idowu James Fasakin , Department of Agricultural Economics, University of Ibadan, Ibadan, Nigeria 
and therefore does not make use of the available resources effectively. With abundant fertile agricultural land and favourable weather condition for maize production, yet Nigeria import maize product about 215,189 tons of maize for her citizens in 2016/2017 season (World Atlas, $2017 \mathrm{a}$, b). Hence, this study will examine the determinants of technical efficiency of maize producing-farmers and causes of inefficiencies among maize farmers in the study area. It is expected that the findings from this study will provide useful information and technical advice to maize farmers in Oyo state and Nigeria in general.

\section{MATERIALS AND METHODS}

Primary data was collected through the use of well structured questionnaire to elicit information on household's expenditure on maize output, socioeconomic characteristics, demographic factors and income of crop farmers.

A multi-stage sampling technique was employed in the study. The first stage was the purposive selection of Oyo state out of the six states in South-Western Nigeria. The second stage was proportionate to size sampling of Local Government Areas (LGAs) in the state. Five LGAs (Egbeda, Akinyele, Ogbomosho North, Ogbomosho South and Ibarapa East) were proportionately selected from the state. The third stage was the random selection of three villages in each of the LGAs selected. This gives a total of fifteen villages. The last stage was proportionate to size sampling of households in the selected villages. In all, a total number of 200 questionnaires were administered, however, due to inadequate information given by the respondents, 180 were found useful for analysis. Households were sampled from selected villages using probability proportionate to size of the population.

Based on the objectives of the study, the analytical tools used were descriptive statistics and stochastic frontier analysis. Descriptive statistics such as percentage, charts and mean were used to describe the household's socioeconomic characteristics. Stochastic Frontier analysis was used to identify the determinants the efficiency and identified the sources of inefficiencies of maize farmers in the study area. The stochastic frontier function is typically specified as:

$$
Y_{i}=f\left(X_{i j} ; \beta\right)+V_{i}-U_{i}(i=1,2, n)
$$

Where:

$\mathrm{Y}_{\mathrm{i}}$ : Output of the ith firm

$X_{i j}$ : Vector of actual jth inputs used by the ith firm

$\beta$ : Vector of production coefficients to be estimated

$\mathrm{V}_{\mathrm{i}}$ : Systematic error which account for random variations. Random variability in the production that cannot be influenced by the firmand

$\mathrm{U}_{\mathrm{i}}$ : The deviation from maximum potential output attributable to technical inefficiency of ith farmer
The above specifications have been expressed in terms of a production function with the $\mathrm{U}_{\mathrm{i}}$ interpreted as technical inefficiency effects which cause the firm to operate below the stochastic production frontier:

$$
\operatorname{LnC}_{a}=f\left(P_{a}, Y_{a}: \beta\right)+\left(V_{i}-U_{i}\right)
$$

Where:

$\mathrm{Y}_{\mathrm{a}}$ : Output of the ith firm

$\beta$ : Parameters to be estimated

$\mathrm{V}_{\mathrm{i}}$ : Systematic component which represents random disturbance cost due to factors outside the scope of the firm

$\mathrm{U}_{\mathrm{i}}$ : One sided disturbance term used to represent cost inefficiency and is independent of

The production efficiency $(\mathrm{CE})$ of an individual firm is defined in terms of the ratio of observed Cost $\left(\mathrm{C}_{\mathrm{b}}\right)$ to the corresponding minimum Cost $\left(\mathrm{C}_{\min }\right)$ under a given technology:

$$
\begin{gathered}
\text { Technical Efficiency }(T E)=\frac{Y_{i}}{Y_{i}^{*}} \\
T E=f\left(X_{i}, E\right) \exp \left(V_{i}-\frac{U_{i}}{f}\right)\left(X_{i}, E\right) \exp \left(V_{i}\right) \\
T E=\exp \left(-U_{i}\right)
\end{gathered}
$$

Where:

$\mathrm{Y}_{\mathrm{i}}$ : The observed output

$\mathrm{Y}_{\mathrm{i}}^{*}$ : The frontier output

Literature reveals that Cobb-Douglass and Translog production functions are the most widely used functional forms in agriculture production functions. However, Translog production form suffers from multicollinearity problem as a result of the square and interaction terms of the input use. The stochastic frontier model in this study is specified as:

$$
\ln Y_{i}=\beta_{0}+\beta_{i} \ln X_{y}+\beta_{2} \ln X_{2}+\ldots, V_{i j}-U_{i j}
$$

Where:

$\mathrm{P}_{1}:$ Ln of fertilizer $(\mathrm{kg})$

$\mathrm{P}_{2}:$ Ln of seed $(\mathrm{kg})$

$\mathrm{P}_{3}:$ Ln of herbicides (L)

$\mathrm{P}_{4}:$ Ln of labour (Naira/manday)

$\mathrm{P}_{6}:$ Ln of farmsize (Hectares)

$\mathrm{Y}_{1}:$ Lnoutput of maize produced in $(\mathrm{kg})$

The $\mathrm{V}_{\mathrm{i}}$ are random variables which are assumed to be normally distributed $N(0, \sigma)$ and independent of the which are non-negative random variables, assumed to be half normally distributed $\left|\mathrm{N}\left(0, \Sigma_{\mathrm{u}} 2\right)\right|$ and account for the cost inefficiency in production (Bravo-Ureta and Evenson, 1994). 
Agric. J., 14 (4): 70-74, 2019

Inefficiency model: The production inefficiency model is specified as follows:

$$
\mathrm{U}_{\mathrm{ij}}=\mathrm{a}_{0}+\mathrm{a}_{1} \mathrm{Z}_{1}+\mathrm{a}_{2} \mathrm{Z}_{2}+\mathrm{a}_{3} \mathrm{Z}_{3}+\mathrm{a}_{4} \mathrm{Z}_{4}+\ldots, \mathrm{a}_{7} \mathrm{Z}_{7}
$$

Where:

$\mathrm{Z}_{1}$ : Age of farmers (year)

$Z_{2}$ : Primary occupation

$\mathrm{Z}_{3}$ : Farming experiences (year)

$\mathrm{Z}_{4}:$ Access to extension (1 contacted, 0 otherwise)

$Z_{5}:$ Sex $($ Female $=0,1=$ Male $)$

$\mathrm{Z}_{6}$ : House hold sizes

$\mathrm{Z}_{7}$ : Marital status

The inefficiency model will be estimated for the maize farmers in the study area in order to determine the factors affecting inefficiency. $U_{i j}$ provides information on level of the allocative efficiency of the ith farm (Ayinde et al., 2015; Battese and Coelli, 1995).

\section{RESULTS AND DISCUSSION}

As shown in Table 1, majority $70.56 \%$ of the farmers are male while $29.44 \%$ are female. The age distribution indicated that $48.33 \%$ of the farmers are within age $41-60$ with the mean age of $44(+0.66)$ year, this indicates that majority of the farmers will have enough experience for their production. Majority $57.22 \%$ are married and had mean household size of $5(0.43), 20.00 \%$ are single with mean household size of 4.46 while $(13.89 \%)$ of the female crop farmers are divorced with mean household size of $5.09,83.89 \%$ of the farmers have between $0-10$ years of farming experience with $12.22 \%$ having $11-20$ years of farming experiences. This indicated that majority of the farmers are new entrant into maize production and this might have effect on their efficiency. Extension service access was poor in the study area with $32.78 \%$ having access to extension service while $67.22 \%$ didn't have access to extension service. Access of the farmers to credit was low with only $34.44 \%$ of the farmer access to credit while $65.56 \%$ did not have access. The distribution of the household size indicates that $56.11 \%$ have between $0-4$ household size while $42.78 \%$ have household size of 5-8 members. This might likely contribute to low family labour among the maize farmers. The distance from the farms to market indicated that $76.11 \%$ covered between $0-20 \mathrm{~km}$ while $17.12 \%$ covered distance between 21-40 km before getting their produce to the market. The results further show that the mean size of farmland owned by the households was 19.12 ha with $54.44 \%$ owned between ( $0-10$ ha) while $31.11 \%$ cultivate between 11-20 ha of land. Total income generated in a year indicated that $91.67 \%$ of the respondents had an income between ( $\mathrm{N} 0-100,000)$ with $7.78 \%$ having an income of ( $\$ 100,001-500,000)$, only $0.56 \%$ of the farmers realized
Table 1: Socio-economic characteristics of the respondents

\begin{tabular}{|c|c|c|c|}
\hline $\begin{array}{l}\text { Socio-economic } \\
\text { characteristics }\end{array}$ & $\begin{array}{c}\text { Frequency } \\
(\mathrm{n}=180)\end{array}$ & Percentage & Means \\
\hline \multicolumn{4}{|l|}{$\begin{array}{l}\text { Sex } \\
\end{array}$} \\
\hline Male & 127 & 70.56 & \\
\hline Female & 53 & 29.44 & \\
\hline \multicolumn{4}{|l|}{ Age (years) } \\
\hline$\leq 20$ & 5 & 2.78 & 44.66 \\
\hline $21-40$ & 65 & 37.78 & \\
\hline $41-60$ & 87 & 48.33 & \\
\hline$>60$ & 20 & 11.12 & \\
\hline \multicolumn{4}{|l|}{ Marital status } \\
\hline Single & 36 & 20 & \\
\hline Married & 103 & 57.22 & \\
\hline Divorced & 25 & 13.89 & \\
\hline Separated & 16 & 8.89 & \\
\hline \multicolumn{4}{|l|}{ Education level } \\
\hline No education & 37 & 21.12 & \\
\hline Primary & 38 & 20.56 & \\
\hline Secondary & 64 & 35.56 & \\
\hline Tertiary & 41 & 22.78 & \\
\hline \multicolumn{4}{|c|}{ Farming experience (years) } \\
\hline$\leq 10$ & 151 & 83.89 & 7.11 \\
\hline $11-20$ & 22 & 12.22 & \\
\hline$>20$ & 7 & 3.89 & \\
\hline \multicolumn{4}{|c|}{ Access to extension } \\
\hline Yes & 59 & 32.78 & \\
\hline No & 121 & 67.22 & \\
\hline \multicolumn{4}{|l|}{ Access to credit } \\
\hline Yes & 62 & 34.4 & \\
\hline No & 118 & 65.56 & \\
\hline \multicolumn{4}{|l|}{ Household size } \\
\hline$\leq 4$ & 101 & 56.11 & 4. $(+-0.34)$ \\
\hline $5-8$ & 77 & 42.78 & \\
\hline$>9$ & 2 & 1.12 & \\
\hline \multicolumn{4}{|c|}{ Distance to market (km) } \\
\hline $0-20$ & 137 & 76.11 & 18.23 \\
\hline $21-40$ & 31 & 17.12 & \\
\hline$>41$ & 12 & 6.66 & \\
\hline \multicolumn{4}{|l|}{ Farm size } \\
\hline $0-10$ & 98 & 54.44 & 19.12 \\
\hline $11-20$ & 56 & 31.11 & \\
\hline$>20$ & 26 & 14.44 & \\
\hline \multicolumn{4}{|c|}{ Total income (Naira) } \\
\hline$\leq 100,000$ & 165 & 91.67 & 51512.22 \\
\hline $100,001-500,000$ & 14 & 7.78 & \\
\hline$>1000000$ & 1 & 0.56 & \\
\hline
\end{tabular}

Field survey, 2019

above $\$ 500,000.00$ in their maize farm operation. This indicated that the farmers in the study area are peasant farmers judging by their level of income.

Table 2 shows the Maximum Likelihood Estimate (MLE) of the stochastic frontier analysis of maize farmers in Oyo state, Nigeria. From the result obtained, the sigma-square $(\delta 2)$ estimate of $1.43(\alpha 0.060)$ confirms to the correctness and good fit of the model while the gamma $(\gamma)$ estimate of $0.58(\alpha 0.082)$ indicates the amount of variation in output of maize resulting from the technical inefficiencies of the maize farmers. This means that $58 \%$ of the variation in maize farmer's output was due to technical efficiency.

Also, the results further reveal that the variables as herbicides, seeds, labour and farm size are factors which 
Agric. J., 14 (4): 70-74, 2019

Table 2: Estimates of stochastic frontiers analysis and inefficiency model

\begin{tabular}{|c|c|c|}
\hline Variables & Parameters & Coefficients/SE \\
\hline Fertilizers & $\mathrm{P}_{1}$ & $\begin{array}{l}-0.043 \\
(0.031)\end{array}$ \\
\hline Seeds & $\mathrm{P}_{2}$ & $\begin{array}{l}0.276 \\
(0.504)^{* * *}\end{array}$ \\
\hline Herbicides & $\mathrm{P}_{3}$ & $\begin{array}{l}0.077 \\
(0.030)^{*}\end{array}$ \\
\hline Labour & $\mathrm{P}_{4}$ & $\begin{array}{l}0.105 \\
(0.031)^{* *}\end{array}$ \\
\hline Farm size & $\mathrm{P}_{5}$ & $\begin{array}{l}0.0524 \\
(0.041)\end{array}$ \\
\hline Insecticides & $\mathrm{P}_{6}$ & $\begin{array}{l}-0.027 \\
(0.031)\end{array}$ \\
\hline Constant & $\mathrm{C}$ & $\begin{array}{l}5.972 \\
(0.336)^{* * *}\end{array}$ \\
\hline \multicolumn{3}{|c|}{ Inefficiency model estimates } \\
\hline Age & $\mathrm{Z}_{1}$ & $\begin{array}{l}0.003 \\
(0.001)^{* *}\end{array}$ \\
\hline Household size & $\mathrm{Z}_{2}$ & $\begin{array}{l}0.020 \\
(0.011)^{*}\end{array}$ \\
\hline Education level & $\mathrm{Z}_{3}$ & $\begin{array}{l}0.001 \\
(0.007)\end{array}$ \\
\hline Farming experiences & $\mathrm{Z}_{4}$ & $\begin{array}{l}0.000 \\
(0.007)\end{array}$ \\
\hline Membership of co-op & $Z_{5}$ & $\begin{array}{l}0.044 \\
(0.022)^{*}\end{array}$ \\
\hline Access to credit & $\mathrm{Z}_{6}$ & $\begin{array}{l}-0.044 \\
(0.312)\end{array}$ \\
\hline Sex & $\mathrm{Z}_{7}$ & $\begin{array}{l}-0.009 \\
(0.028)\end{array}$ \\
\hline $\begin{array}{l}\text { Diagnostic statistics } \\
\text { Sigma square }\end{array}$ & $\delta^{2}$ & 1.430 \\
\hline Gamma & $\gamma$ & $\begin{array}{l}(0.060) \\
0.082 \\
(0.582) \\
\text { Prob } \geq=\text { chibar2 }=0.006\end{array}$ \\
\hline
\end{tabular}

Log likelihood $\quad-223.46193$

Researchers computation $2019,{ }^{* * *}, * *, *$ rep sig at 1,5 and $10 \%$, respectively

influence the quantity of outputs of maize positively in the study area. The coefficient of herbicides quantity was significant at $(p<0.01)$ indicating that an increase in the quantity of herbicide used by the maize farmers will lead to increase in the quantity of output of maize produced by the farmers. The seed quantity had a positive coefficient and was statistically significant $(\mathrm{p}<0.10)$, indicated that a percentage increase in the quantity of seed planted would result in 50\% increase in maize output. This finding is in line with Ayinde et al. (2015), Oyewo (2011) and where seed quantity was an important variable in maize technical efficiency study. Labour coefficient was significant ( $p>0.05$ ) with a positive coefficient while farm size also have positive estimated elasticity of 0.05 implying that increase in these variables will also increase the quantity of maize produced. These findings were in tandem with Ayinde et al. (2015).

Sources of inefficiencies: As indicated in the Table 2 the results of the inefficiency model shows that age $(p<0.05)$, household size $(p<0.10)$ and membership of cooperative association $(p<0.10)$ of the respondents are $(p<0.05)$, household size $(p<0.10)$ and membership of
Table 3: Efficiency scores

\begin{tabular}{lcc}
\hline Efficiency & Frequency & Percentage \\
\hline $0.05-0.39$ & 45 & 25.28 \\
$0.40-0.49$ & 29 & 16.29 \\
$0.50-0.69$ & 83 & 46.63 \\
$0.70-0.89$ & 16 & 8.99 \\
$0.80-1.00$ & 05 & 2.81 \\
Total & 178 & 100 \\
Mean efficiency score & 0.52 & \\
Max efficiency score & 0.82 & \\
Min efficiency score & 0.051 &
\end{tabular}

ency score

Field survey, 2019

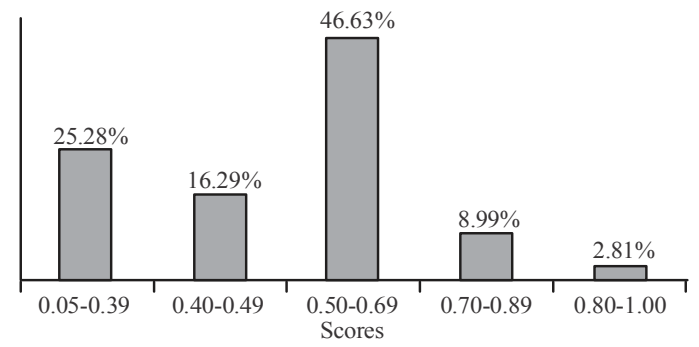

Fig. 1: Eficiency scores chart

cooperative association $(\mathrm{p}<0.10)$ of the respondents are significant determinants of technical inefficiency. The sign of the variables in the inefficiency model is very important in explaining the observed level of technical efficiency of the farmers. A negative sign implied that the variable had the effect of reducing technical inefficiency of the maize farmers, hence, increasing farmer's production efficiency while a positive coefficient indicate that the variable has the propensity of increasing inefficiency, thus, reducing farmer's production efficiency. Therefore, an increase in household size, age, education and farming experiences would significantly increase production efficiency of the farmers. This underscores the fact inherent in many literature that farmers usually rely on household labour to boost production given it availability, less cost and ease of manipulation to suit different farm activities. Also as the farmers get older, they garnered more experience in their production activities, since, they have been practicing it for long. So, also is the education level or qualifications of the farmers. A well educated farmers would have acquired more education skills to improve his production efficiency. Access to credit by the farmers had a negative coefficients. This indicated that farmers in the study area lack access to credit to increase their production.

The technical efficiency scores was indicated in Table 3 from the table, the maximum technical efficiency of the farmers was 0.82 , mean was 0.52 and minimum was 0.051 . These statistics indicated that the available resources for the maize farmers were not totally utilized for their production, judging by 0.52 mean technical efficiency score. Hence, maize farmers in the study area need to improve on their production skills in order to maximize their efficiencies. The efficiency scores are further shown in the chart in Fig. 1. 
Agric. J., 14 (4): 70-74, 2019

\section{CONCLUSION}

The stochastic frontiers analysis result indicated that herbicides quantity, seeds, labour and farm size are factors which influence the quantity of outputs of maize positively while the source of inefficiencies are age, household size and membership of co-operative association. The study, therefore, recommended that maize seed should be made available to farmers at a reduced rate, tractors and other farm inputs should be supplied at affordable rate to reduce higher cost on labour and reduced inefficiencies due to old age.

\section{REFERENCES}

Ayinde, I.A., R.O. Aminu and S.B. Ibrahim, 2015. Technical efficiency of maize production in Ogun State, Nigeria. J. Dev. Agric. Econ., 7: 55-60.

Battese, G.E. and T.J. Coelli, 1995. A model for technical inefficiency effects in a stochastic frontier production function for panel data. Empir. Econ., 20: 325-332.

Bravo-Ureta, B.E. and E.R. Evenson, 1994. Efficiency in agricultural production: The case of peasant farmers in Eastern Paraguay. Agric. Econ., 10: 27-37.

FAO, 2013a. FAO Statistical Year Book 2012. Food and Agricultural Organization, Rome, Italy.
FAO., 2013b. Top maize production. Food and Agriculture Organization, Rome, Italy.

FAO., 2017. FAOSTAT database: Food and Agriculture Organization of United (Rome). National Production Statistics Nigeria, Food and Agriculture Organization, Rome, Italy.

Monsanto, 2014. Water Efficient Maize for Africa (WEMA): Improved maize varieties to aid farmers in Sub-Saharan Africa. Monsanto Agrochemical Company, St. Louis, Missouri, USA.

Olaniyan, A.B., 2015. Maize: Panacea for hunger in Nigeria. Afr. J. Plant Sci., 9: 155-174.

Oyewo, I.O., 2011. Technical efficiency of maize production in Oyo State. J. Econ. Int. Finance, 3: 211-216.

Rana, J.B., J.P. Singh, S. Kumar and V.K. Shahni, 2018. Maize production viability-a study of economics, constraints and policy implications for Eastern Uttar Pradesh, India. Int. J. Curr. Microbiol. Applied Sci., 7: 2776-2783.

World Atlas, 2017a. Crop production quantity, maize production in Nigeria. Atlas World Group Company, Evansville, Indiana.

World Atlas, 2017b. Most important staple foods in the world. Atlas World Group Company, Evansville, Indiana. 